\title{
Olfactory recognition of terrestrial shelters in female Northern Spectacled Salamanders Salamandrina perspicillata (Caudata, Salamandridae)
}

\author{
Antonio Romano ${ }^{1}$ and Antonio Ruggiero \\ Dipartimento di Biologia, Università degli studi di Roma “Tor Vergata”, Via della Ricerca Scientifica, 00133 Rome, \\ Italy. \\ ${ }^{1}$ Present address: Via Creta 6, 04100 Latina (LT), Italy. E-mail: antonioromano71@ tele2.it.
}

\begin{abstract}
Olfactory recognition of terrestrial shelters in female Northern Spectacled Salamanders Salamandrina perspicillata (Caudata, Salamandridae). Chemical cues are used as ubiquitous markers of individual, group, kinship, and species identity. Northern Spectacled Salamander (Salamandrina perspicillata) is a semi-terrestrial and elusive species. Females can be found in water bodies just in the spawning season but spend most of their life, as well as males do, in terrestrial shelters such as cracks, crevices and under stones to reduce the risks of dehydration. We have investigated whether, in reproductive females, animal's own and conspecific chemical cues play a role in the shelter choice. We performed unforced "two-choice system" tests in order to study the behavioural response of salamanders to scent marks. For each test, the choice between two artificial shelters (plastic tubes) was offered to each focal individual. Data were analyzed using the binomial distribution. Our results show that Salamandrina use the sense of smell in the terrestrial shelter choice as animals (i) were capable to discriminate between a tube previously used by itself and a unused one $(P<0.001)$ and (ii) preferred a tube previously marked by another female in the place of an unused one $(P<0.05)$. However discrimination between individual's own odour and that of a conspecific one was not significant $(P>0.05)$. We suggest that attraction towards conspecific smells could favour a gregarious behaviour in winter refuges.
\end{abstract}

Keywords: Caudata, Salamandridae, Salamandrina perspicillata, olfactory recognition, terrestrial shelters, Central Italy.

\begin{abstract}
Riassunto
Riconoscimento olfattivo dei rifugi terrestri nelle femmine di Salamandrina dagli occhiali settentrionale Salamandrina perspicillata (Caudata, Salamandridae). Le percezioni olfattive sono ampiamente usate nel mondo animale per discriminare tra individui, gruppi, consanguinei e tra specie. La Salamandrina dagli occhiali settentrionale (Salamandrina perspicillata) è una specie semi terrestre e dal compor-
\end{abstract}

Received 11 February 2008.

Accepted 11 April 2008.

Distributed September 2008. 
tamento elusivo. Le femmine adulte si recano in acqua solo durante il periodo della deposizione delle uova mentre trascorrono la maggior parte della loro vita, così come fanno i maschi, in ambiente terrestre, rifugiandosi, per ridurre al minimo il rischio di disidratazione, in fessure delle rocce, sotto massi e tronchi. Utilizzando femmine riproduttive, abbiamo effettuato un esperimento per testare se le tracce chimiche lasciate sul substrato da ogni individuo e quelle lasciate da altre femmine avevano un ruolo nella scelta del rifugio terrestre. Per verificare questo abbiamo condotto una serie di test non forzati con possibilità di una doppia scelta del rifugio. In ogni test infatti ogni salamandrina poteva scegliere tra due rifugi artificiali (piccoli tubi in plastica) che differivano per le tracce chimiche in essi lasciate. I dati sono stati analizzati usando la distribuzione binomiale. I risultati indicano che l'olfatto guida le salamandrine nella scelta del rifugio. Infatti gli animali erano in grado di $(i)$ discriminare tra i tubi marcati da loro stessi e quelli privi di odori $(P<0.001)$ e di $($ ii $)$ discriminare tra tubi marcati da un'altra femmina e quelli privi di odore $(P<0.05)$. Tuttavia le salamandrine non hanno mostrato una netta preferenza tra il proprio odore e quello di altre femmine $(P>0.05)$. L'attrazione verso l'odore di conspecifici potrebbe favorire un comportamento gregario nei rifugi terrestri, fenomeno già noto per altre specie di urodeli.

Parole Chiave: Caudata, Salamandridae, Salamandrina perspicillata, riconoscimento olfattivo, rifugi terrestri, Italia.

\section{Introduction}

Animals live in a chemical world. Olfaction plays a key-role in food recognition, sexual selection and orientation along either aerial or terrestrial scent trails. Organisms use chemical cues as ubiquitous markers at individual and/or group level to set up kinship and species identity (Stoddart 1980, England et al.1999, Stoka 1999, Wyatt 2003). Several studies have shown that also amphibians, that is Anura (e.g. Jungfer 1942, Waldman and Bishop 2004), Caudata (e.g. Duelman and Trueb 1986, Joly and Miaud 1993, Gautier et al. 2006, Dantzer and Jaeger 2007) and Gymnophiona (e.g. Warbeck et al.1996), largely use the sense of smell.

Despite the fact that Salamandrina deserves distinctive attention due to its endemicity and specific reproductive characteristics (Andreone and Luiselli 2000), this endemic Italian salamander is among the poorly studied
European amphibians. The information on ethology and ecology of Northern spectacled salamander S. perspicillata (Savi 1821) and Southern spectacled salamander $S$. terdigitata (Bonnaterre 1789) are very scanty. So far, only one study, concerning the behaviour of Salamandrina perspicillata in relation to the sense of smell, is available (Romano et al. 2007). In this study authors showed that $S$. perspicillata is capable to recognise the water of its own breeding site with respect to that from different places. Summer and winter habitat of Salamandrina is the ground layer constituted by moss, dead leafs, barks, little and medium size stones (Zuffi 1999). During summer and winter the spectacled salamander has been found between 20-135 cm underground (Bruno 1973, Vanni 1980, Lanza 1983), but on average there is scanty available information on terrestrial shelter used by $S$. perspicillata. Furthermore in spring and summer some salamanders have been found between $130-170 \mathrm{~cm}$ from the 
ground in the clefts of vertical rocks near breeding sites (A. Romano unpubl. data).

Shelter and substrate choice is commonly affected by scent marks in other terrestrial salamanders. For Salamandra lanzai, Mertensiella luschani and for many species of American plethodontids, the results of experiments provided detailed information on preferences among sexes and among different life stages, i.e. adult females, adult males and juveniles (e.g. Gillette 2002, Gautier et al. 2004, 2006). The aim of this study was to test the use of scent cues in terrestrial shelter selection of $S$. perspicillata and the role of conspecific scents in this selection.

\section{Materials and Methods}

Smell relationships between sexes are unknown in Salamandrina, and female and males are morphologically almost indistinguishable for this species (Lanza 1983, Brizzi et al. 1989). However we were able to collect a sample of females only thanks to the particular behaviour of this species during its reproductive season. In fact, in Salamandrina only females show an aquatic phase. This aquatic phase is limited to the oviposition activity (e.g. Lanza 1983) which lasts for less than one week on average (Della Rocca et al. 2005, Angelini et al. 2006). We thus performed our experiment with females only, as animals were collected in water bodies during spawning.

The sampling site was located on the Lepini Mounts (Latium, Central Italy, Figure 1). Here the oviposition period extends from around the end of February to around the end of April, while the highest concentration of salamanders occurs during the second half of March, when hundreds of spawning females can be found (pers. obs.). On the $23^{\text {rd }}$ of March 2006, we collected 180 females of $S$. perspicillata in a breeding site located in the Lepini Mounts. We chose females with unswollen belly which probably were close to the end of their spawning activity and therefore, ready to come

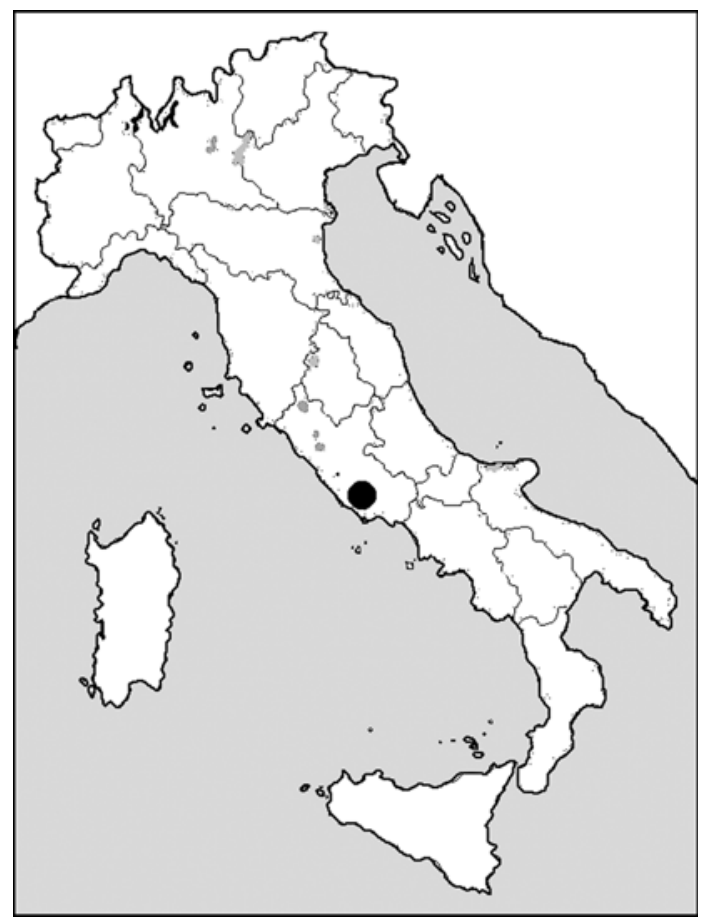

Figure 1 - Map of Italy and sampling site in which 180 salamanders (Salamandrina perspicillata) were collected for the experiment.

back to terrestrial shelters. In fact females usually enter the water only once to lay eggs during each reproductive season (e.g. Della Rocca et al. 2005).

We housed each salamander in an artificial shelter (plastic tube $9 \mathrm{~cm}$ in length, $3 \mathrm{~cm}$ in diameter, Figure 2) it being never in contact with the other salamanders. We maintained individuals for 16 hours in their shelters to mark each tube with their own scent. This time is approximately the same adopted to mark pipes during experiment performed with other species of salamanders (i.e. 18 hrs; Gautier and Miaud 1999, Gautier et al. 2004, 2006). We closed the shelter openings by wet cotton to prevent the dehydration of animals. We also applied wet cotton to empty tubes used in the tests as freescent shelters, to avoid differences in humidity 
among shelters. We wetted the cotton using water of the breeding site to avoid differences in the odour caused by different types of water because this species is able to discriminate among scents of different types of water (Romano et al. 2007). All tests took place in the same place, close to the sampling site. We released all the salamanders at the sampling site after the experiment. We used thirty salamanders just to mark the shelters and they were not included in the "two-choice system" tests for which we used a total of 150 salamanders.

We performed three (A, B and C) unforced "two-choice system" tests in order to study the behavioural response of $S$. perspicillata to scent marks. In a given test, we offered a choice between two alternative shelters to each focal salamander. In test A, 60 salamanders had the possibility to choose between a shelter marked by their own scent (OWN) and a free-scent shelter (FSS). We thus tested whether spectacled salamanders used their own scent deposited in a refuge to decide whether to choose this shelter or not. In test B, 60 salamanders had the possibility to choose between a shelter marked by scent of another female (OTH) and a FSS. We thus tested whether spectacled salamanders used scent deposited by other females in a refuge to decide whether to choose this shelter or not. In test C, 30 salamanders had the possibility to choose between a OWN and a OTH. The aim was to detect if spectacled salamanders showed a preference in their shelter choice between a refuge marked by their own odour and another one where scent of another female was deposited.

At the beginning of each test, we placed the focal animal in the middle of an opaque plastic box $(26 \times 36 \times 10 \mathrm{~cm}$, Figure 3$)$, which was immediately closed with an opaque plastic lid, and we randomly located the two shelters at the opposite-ends of the box. We used 150 different plastic boxes, i.e. one box for each focal salamander. In each test we recorded the position of the salamander in four occasions (trials), one every 60 minutes. Whenever we

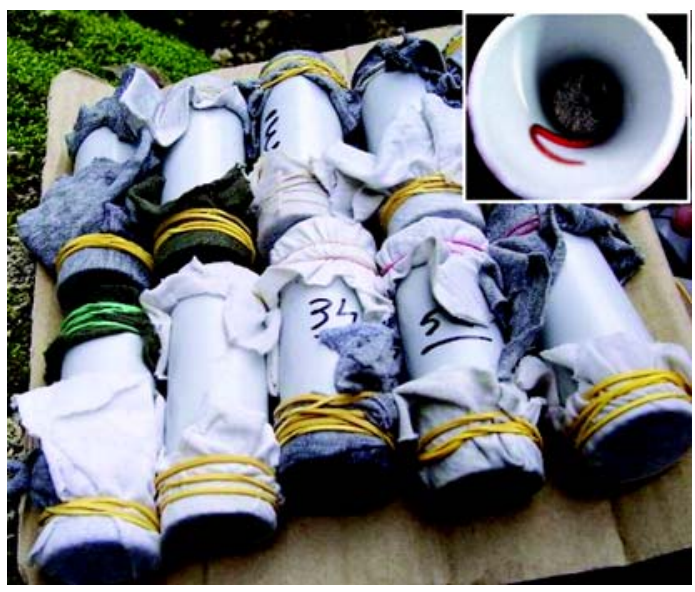

Figure 2 - The plastic artificial shelters where we housed each salamander for 16 hours to mark the tube with their own scent. The square shows a salamander in its own tube.

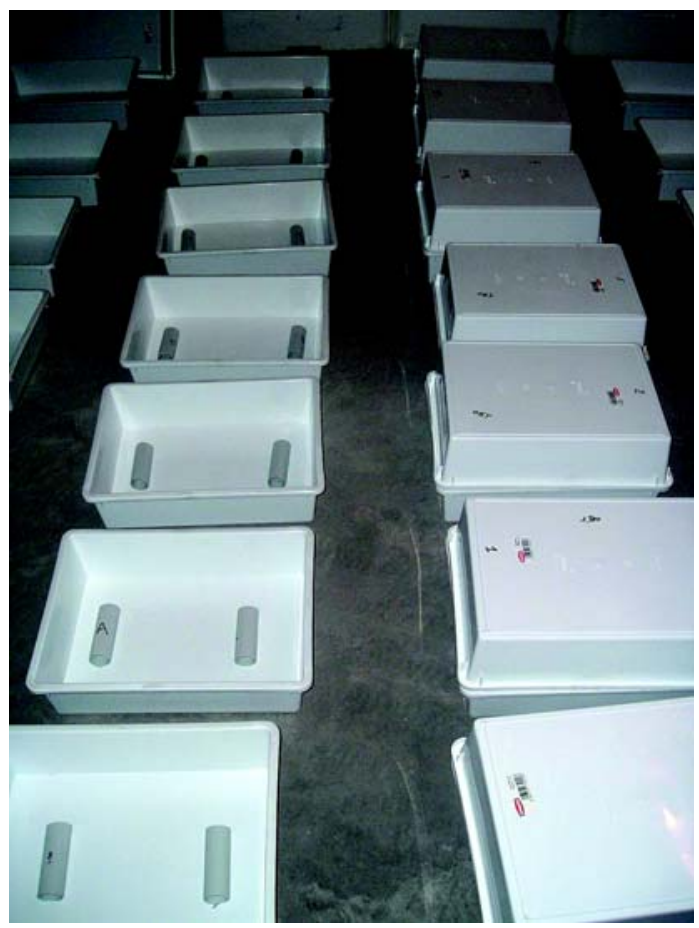

Figure 3 - Opaque plastic boxes used in the experiments. On the left: open boxes in which plastic tube at the opposite ends of the boxes are visible. On the right: boxes with their opaque plastic lids. 
found a salamander in FSS or in a shelter marked by another female, we substituted this shelter with an analogous one and the focal animal was replaced in the middle of its own box. Whenever we found a salamander in OWN, the focal animal was replaced in the middle of its own box without we substituted this shelter as in this case no contrasting or ambiguous stimulus would be perceived by the salamander.

At the end of a test, we assigned "no choice" to those salamanders that never chose a shelter in all trial. Accordingly we assigned a given choice to those salamanders that chose a given shelter for a higher number of times than the other available one. When the number of observations was lower than twenty, the standard table of the binomial distribution was used (Siegel and Castellan 1988). We carried out statistical analyses in the experiment $\mathrm{A}$ and B using one tailed test. Conversely, in the experiment $\mathrm{C}$ we used a two-tailed test, because there was not a priori reasons to expect a preference between OTH and OWN stimuli.

In each experiment, we used the multiple Chi square analyses to test whether the number of choices differed among the four trials. Data were analysed using Fisher's sign test using Statistica ${ }^{\circledR}$ ver. 6.0 (Statistica package, Statsoft Inc., USA).

\section{Results}

The results of the three tests are resumed in Figure 4. Many of salamanders never chose a shelter $(63 \%)$ and no salamander chose for an equal number of times the two alternative shelters. Results of test A indicate that salamanders preferred the shelters where they were previously housed compared to FSS $(P<0.001 ; \mathrm{N}=24)$. Results of test B indicate that salamanders preferred shelters marked by scent of other females in comparison to FSS $(P<0.05$; $\mathrm{N}=12$ ). In the test $\mathrm{C}$, salamanders seemed slightly to be attracted more by shelters marked by conspecific females compared to shelters

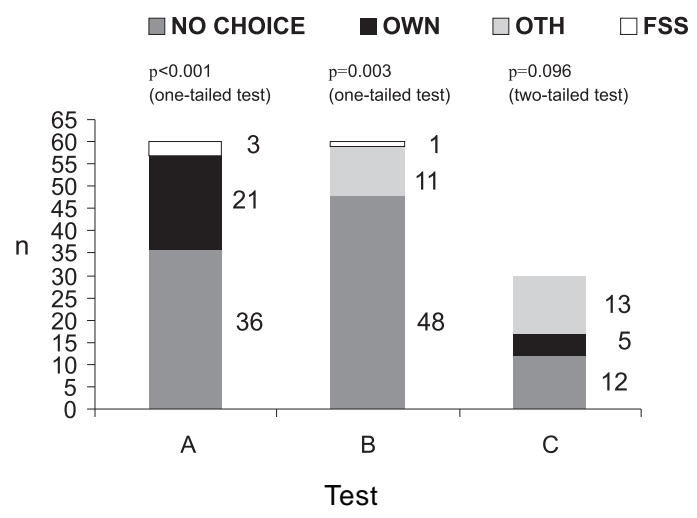

Figure 4 - Two-choice system tests performed in order to study the behavioural response of Salamandrina perspicillata to scent marks in terrestrial shelters. Test A: in this test each salamander chose between an artificial shelter marked by its own scent (OWN) and a free-scent shelter (FSS). Test B: each salamander chose between shelters marked by other female odour (OTH) and a FSS. Test C: each salamander chose between OWN and FSS. Number of salamanders that chose a given option was reported. NO CHOICE indicate the number of salamanders that did not choose any shelter (see the text for details). Results of Fisher's sign test are reported above each bar.

marked by their own scent, but this pattern is not significant $(P=0.096 ; \mathrm{N}=18)$.

Multiple Chi square analyses show that there were no significant differences in the number of choices among the four trials in the experiment $\mathrm{A}$ and in the experiment $\mathrm{C}$ (Chi square $=0.73$ and 1.13 respectively, gdl $=3$ and $P>0.5$ in both experiments). On the contrary, differences in the number of choices among the four trials in the experiment $\mathrm{B}$ were significant (Chi square $=$ 8.11; $\mathrm{gdl}=3, P<0.05)$.

\section{Discussion}

This study provides first observations on the sense of smell used by Salamandrina perspicillata to choose among terrestrial shelters. In two experiments (A and C) the results obtained 
among trials in each experiment did not differ while in the experiment $B$ there was a significant difference. However, contrarily to our expectations, in the experiment $\mathrm{B}$ most of choices were not made in the first trail where just one salamander chose a shelter. This pattern contrasts to the one observed in Salamandra lanzai (Gautier and Miaud 1999, Gautier et al. 2004) for which most of the results were obtained at the first record (C. Miaud pers. com.).

Differently from other salamanders, which were tested using analogous experiments (Gautier et al. 2004, 2006), a low number of spectacled salamanders chose to enter shelter (37\%). This scarce propensity to choose refuges may be due to the life stage in which animals were tested, i.e. reproductive season. On the other hand this is the only opportunity to find, simultaneously, a sufficient number of specimens of know sex to perform this type of experiment. We think that further experiments, considering also different procedures and sampling methods, should be addressed to clarify the question about the scarce propensity to enter shelter showed by this salamander.

Terrestrial or semi-terrestrial urodeles spend a significant part of their lives in shelters that protect them from dehydration. Strong site fidelity is common among terrestrial salamanders in particular (Jaeger and Forester 1993, Mathis et al. 1995, Ribéron and Miaud 2000). Northern Spectacled Salamanders leave water bodies and search cavities, natural holes and other refuges after spawning activity (Bruno 1973, Vanni 1980). Salamandrina perspicillata was able to discriminate among shelters previously used by conspecific salamanders and unused ones. However they seemed unable to discriminate between their own odour and the odour of conspecific ones, or, at least, this capability did not affect their behaviour in the experimental conditions (see results of test C). As a whole, results from the three tests suggest an aggregative behaviour (Graves and Duvall 1995) because in the case of scent-marking behaviour for territorial porpouses, only the preference of self marks is expected (Gosling 1982). In particular, females of $S$. perspicillata salamanders cannot discriminate their own scent from the chemical cues of other conspecific females. This result agrees to that obtained for Mertensiella luschani by Gautier et al. (2006). To date, data on shelter fidelity and gregarious behaviour of Salamandrina are unavailable. However, one or more spectacled salamanders may occupy the same terrestrial refuge near spawning sites (Romano, unpublished data).

On the basis of our findings, detection of the scent of conspecific in terrestrial environment could be considered as one of the mechanisms adopted by these salamanders during the migration towards their terrestrial refuges. Preferences towards shelters occupied by conspecifics could provide some benefits because a portion of salamanders chooses shelters which are suitable for the species, really in these shelters there were already salamanders (i.e. animals are mutually attracted by suitable habitats; Brown and Orians 1970) and further benefits could come from the vicinity of conspecifics, for example for thermoregulation (Graves and Duvall 1995).

Our preliminary work reveals some aspects on the chemical world where the Northern spectacled salamander lives. This study strengthens the idea that a better knowledge of the "sense of smell" and its ecological and autoecological role may provide an important contribution to the conservation and protection of spectacled salamander.

\section{Acknowledgements}

The Italian "Ministero dell'Ambiente e della Tutela del Territorio e del Mare" issued capture permits (DPN/2D/2006/33543). Francesca Romana Venzi and Arnaldo Tramentozzi (Eremo di S. Erasmo, Roccagorga, Latina) provided hospitality and a useful logistic support. Lorenzo Proia provided an important 
support in the field. Sebastiano Salvidio provided stimulating comments, which have been useful to improve the manuscript. We are also grateful to Claude Miaud and another anonymous referee for their helpful comments.

\section{References}

Andreone, F. and L. Luiselli. 2000. The Italian batrachofauna and its conservation status: a statistical assessment. Biological Conservation 96: 197-208.

Angelini, C., D. Antonelli, M. Merlini, M. Panfilio, and C. Utzeri. 2006. Osservazioni sull'ovideposizione di Salamandrina perspicillata (Savi, 1821): tipologia dei siti e permanenza in acqua. Pp. 1-5 in M. A. L Zuffi (ed.), Atti del V Congresso Nazionale della Societas Herpetologica Italica. Firenze. Firenze University Press.

Brizzi, R., G. Delfino and C. Calloni. 1989. Female cloacal anatomy in the spectacled salamander, Salamandrina terdigitata (Amphibia: Salamandridae). Herpetologica 45: 310-322.

Brown, J. L. and G. H. Orians. 1970. Spacing patterns in mobile animals. Annual Review of Ecology and Systematics 1: 239-262.

Bruno, S. 1973. Anfibi d'Italia: Caudata. Natura 64: 209450.

Dantzer, B. J. and R. G. Jaeger. 2007. Male red-backed salamanders can determine the reproductive status of conspecific females through volatile chemical signals. Herpetologica 63: 176-183.

Della Rocca, F., L. Vignoli and M. A. Bologna. 2005. The reproductive biology of Salamandrina terdigitata (Caudata, Salamandridae). Herpetological Journal 15: 273-278.

Duellman, W. E. and L. Trueb (eds.). 1986. Biology of Amphibians. Baltimore. The John Hopkins University Press. 670 pp.

England, R., G. Hobbs, N. Bainton, and D. M. Roberts. 1999. Microbial signalling and communication. Cambridge. Cambridge University Press. 365 pp.

Gautier, P. and C. Miaud. 1999. Individual olfactory recognition of shelter in the terrestrial salamander Salamandra lanzai. Pp. 125-128 in C. Miaud and R. Guyetant (eds.), Current Studies in Herpetology. Le Bourget du Lac, France.

Gautier, P., J. P. Lena and C. Miaud. 2004. Responses to conspecific scent marks and the ontogeny of territorial marking in immature terrestrial salamanders. Behavioural Ecology and Sociobiology 55: 447-453

Gautier, P., K. Olgun, N. Uzum, and C. Miaud. 2006.
Gregarious behaviour in a salamander: attraction to conspecific chemical cues in burrow choice. Behavioural Ecology and Sociobiology 59: 836-841.

Gillette, J. R. 2002. Odor discrimination in the California slender salamander, Batrachoseps attenuatus: evidence for self recognition. Herpetologica 58: 165-170.

Gosling, L. M. 1982. A reassessment of the function of scent marking in territories. Zeitschrift für Tierpsychologie 60: 89-118.

Graves, B. M. and D. Duvall. 1995. Aggregation of squamate reptiles associated with gestation, oviposition, and parturition. Herpetological Monographs 9: 102-119

Jaeger, R. G. and D. C. Forester. 1993. Social behavior of plethodontid salamanders. Herpetologica 49: 163-175

Joly, P. and C. Miaud. 1993. How does a newt find its pond? The role of chemical cues in migrating newts (Triturus alpestris). Ethology, Ecology and Evolution 5: 447-455.

Jungfer, W. 1942. Beiträge zur Biologie der Erdkröte (Bufo bufo L.) mit besonderer Berücksichtigung der Wanderung zu den Laichgewässern. Zeitschrift für Morphologie und Ökologie der Tiere 40: 117-157.

Lanza, B. 1983. Anfibi, Rettili (Amphibia, Reptilia). AQ/ 1/205. Collana del Progetto Finalizzato "Promozione della Qualità dell'Ambiente". Guide per il riconoscimento delle specie animali delle acque interne italiane 27. Consiglio Nazionale delle Ricerche, Roma.

Mathis, A., R. G. Jaeger, W. H. Keen, P. K. Ducey, S. Walls, and B. Buchannan. 1995. Aggression and territoriality in salamanders and a comparison with the territorial behavior of frogs. Pp. 633-676 in $\mathrm{H}$. Heatwole and B.K. Sullivan (eds.), Amphibian Biology, Vol. 2, Social Behaviour. Chipping Norton. Surrey Beatty and Sons.

Ribéron, A. and C. Miaud. 2000. Home range and shelter use in Salamandra lanzai. Amphibia-Reptilia 21: 255260.

Romano, A., G. Forcina and F. Barbanera. 2007. Breeding site selection by olfactory cues in the threatened northern spectacled salamander Salamandrina perspicillata (Savi, 1821). Aquatic Conservation 18. DOI: $10.1002 /$ aqc. 890

Siegel, S. and N. J. Castellan JR. 1988. Nonparametric Statistics for the Behavioral Sciences. $2^{\text {nd }}$ ed. New York. McGraw-Hill. 399 pp.

Stoddart, D. M. 1980. The Ecology of Vertebrate Olfaction. London. Chapman and Hall. 232 pp.

Stoka, A. M. 1999. Phylogeny and evolution of chemical communication: an endocrine approach. Journal of Molecular Endocrinology 22: 207-225.

Vanni, S. 1980. Note sulla Salamandrina dagli occhiali 
Salamandrina terdigitata (Lacépède, 1788) in Toscana (Amphibia: Salamandridae). Atti della Società Toscana di Scienze Naturali, Memorie, ser. B, 87: 35-159.

Waldman, B. and P. J. Bishop. 2004. Chemical communication in an archaic anuran amphibian. Behavioral Ecology 15: 88-93.

Warbeck, A., I. Breiter and J. Parzefall. 1996. Evidence for chemical communication in the aquatic caecilian Typhlonectes natans (Typhlonectidae, Gymnophiona).
Mémoires de Biospéoléogie 23: 37-41.

Wyatt, T. D. 2003. Pheromones and Animal Behaviour Communication by Smell and Taste. Cambridge. Cambridge University Press. 408 pp.

Zuffi, M. A. L.1999. Salamandrina terdigitata (Lacépède, 1788) - Brillensalamander. Pp. 229-246 in Grossenbacher K, Thiesmeir B (eds) Handbuch der Reptilien und Amphibien Europas, Band 4/1, Schwanzlurche (Urodela) I. Aula-Verlag: Wiebelsheim. 